(c) Elsevier/INRA

Note

\title{
Dominant and recessive brown in goats
}

\author{
DP Sponenberg ${ }^{1}, \mathrm{C} \mathrm{LaMarsh}^{2}$ \\ 1 Virginia-Maryland Regional College of Veterinary Medicine, \\ Virginia Tech, Blacksburg, VA 24061; \\ 2 Blue Berry Sunrise Farm Pygmy Goats, 14453 S Macksburg Rd, \\ Molalla, OR 97038, USA
}

(Received 2 May 1995; accepted 18 October 1995)

\begin{abstract}
Summary - Pygmy goats in the USA occur in a variety of colors including black, roan (called agouti by breeders), and badgerface. In a minority of animals the black areas are replaced by dark brown or medium brown. The colors of kids from matings among black, dark-brown, and medium-brown goats were observed. The results are consistent with three alleles at the Brown locus: dark brown $\left(B^{d}\right)$ dominant to wild type $\left(B^{+}\right)$which is dominant to medium brown $B^{b}$ ).
\end{abstract}

goat / genetics / coat color / brown / Pygmy goat

Résumé - Bruns dominant et récessif chez la chèvre. Les chèvres Pygmy des États Unis présentent une variété de couleurs comprenant le noir, le rouan (appelé agouti par les éleveurs), et «face de blaireau» («badger face»). Chez quelques animaux les zones noires sont remplacées par du brun foncé ou du brun moyen. On a observé des chevreaux issus de croisements entre des parents noirs, brun foncé ou brun moyen. Les résultats sont en accord avec l'existence de trois allèles au locus Brun: le brun foncé $\left(N^{d}\right)$ dominant sur le type sauvage $\left(B^{+}\right)$lui-même dominant sur le brun moyen $\left(B^{b}\right)$.

chèvre / génétique / couleur de robe / brun / chèvre Pygmy

\section{INTRODUCTION}

Inheritance of coat color in goats has received less attention than has that of sheep, primarily due to the economic importance of white sheep's wool and lack of a similar importance for color in most goats. Recent work (Adalsteinsson et al, 1994) has documented the similarity of the genetic control of many goat colors to sheep colors.

The relationship of brown to black eumelanin in goats is one aspect of color genetics that has been studied repeatedly with conflicting results. Early works 
include those of Asdell and Buchanan Smith (1928) and Eidregevic (1941), who concluded that brown was dominant to black. This was further substantiated by Hards (1950). Lauvergne and Howell (1978) postulate that both brown and light brown are recessive to black, but segregation data were not available for analysis. Adalsteinsson et al (1994) conclude that light brown, typical of the Toggenburg breed, is dominant to black. The general conclusion one can draw from past work is that brown is dominant to black, and that this brown is the light brown of the Toggenburg breed. Other types of brown have been less well documented by segregation data.

Two types of brown are present in the Pygmy goat breed in the USA. That these are eumelanic is substantiated by the fact that each of these browns is seen in conjunction with the badgerface pattern (termed caramel in this breed) in which the browns replace black in the typical pattern. These two types of brown are distinct, and are easily recognized by breeders. One is a dark brown, and is often called cocoa brown by breeders. This is a very dark brown. The other is a medium brown which is much lighter and brighter than the dark brown, and is termed red by breeders even though it is an eumelanic phenomenon, and not pheomelanic as are most colors termed red by livestock breeders. Medium brown is more rare in the Pygmy breed than dark brown. The light brown of the Toggenburg is not present in the Pygmy breed, is very visually distinct from the two browns in the Pygmy breed, and probably represents a third type of brown in goats.

\section{MATERIALS AND METHODS}

Data from a herd of Pygmy goats in which both dark-brown and medium-brown goats occurred were available for study. Dark-brown goats were used for several matings, and the resulting figures were tested by statistical analysis for goodness of fit to the hypothesis that dark brown is dominant to black. Medium-brown goats were also used for several matings, and the resulting data were tested for goodness of fit to the hypothesis that medium brown is recessive to black.

\section{RESULTS}

The results of various crosses are presented in table I. Black goats mated to black goats produced over 100 kids, none of which were dark brown. The mating of black goats to dark-brown goats produced 23 black and 17 dark-brown kids. These results agree with the hypothesis that dark brown is due to a gene $\left(B^{d}\right)$ that is dominant to black (wild type, $B^{+}$), and that all dark-brown parents are heterozygous $\left(B^{d} B^{+}\right): \mathrm{chi}^{2}=0.9,1 d f, P>0.05$. The mating of dark-brown goats to dark-brown goats produced no black and seven dark-brown kids. These results agree with the hypothesis that dark brown is due to a gene $\left(B^{d}\right)$ that is dominant to black $\left(B^{+}\right)$, and that all parental dark-brown goats are heterozygous $\left(B^{d} B^{+}\right)$, binomial test, $P=0.13$.

Medium-brown goats mated to black goats produced 62 black and four mediumbrown kids. These results do not support the hypothesis that medium brown is due to a gene $\left(B^{b}\right)$ that is dominant to black $\left(B^{+}\right): \operatorname{chi}^{2}=51,1 d f, P<0.01$. 
Table I. Colors produced by various matings in Pygmy goats.

\begin{tabular}{llccc}
\hline \multirow{2}{*}{ Colors mated } & & \multicolumn{3}{c}{ Kids produced } \\
\cline { 3 - 5 } & & Black & Dark brown & Medium brown \\
\hline Black & Black & $100+$ & 0 & 0 \\
Black & Dark brown & 23 & 17 & 0 \\
Dark brown & Dark brown & 0 & 7 & 0 \\
Black & Medium brown & 62 & 0 & 4 \\
Black, with one medium-brown & Medium brown & 42 & 0 & 26 \\
parent & & & & 28 \\
Medium brown & Medium brown & 0 & 0 & 1 \\
$\begin{array}{l}\text { Dark brown, with one medium- } \\
\text { brown parent }\end{array}$ & Medium brown & 0 & 1 & \\
\hline
\end{tabular}

If medium brown is recessive to black, the black goats heterozygous for the gene and those not heterozygous for the gene cannot be adequately separated into two classes even though they represent two different genotypes. Medium-brown goats mated to black goats which had one medium-brown parent (these being obligate heterozygotes under the hypothesis that medium brown is recessive) produced 42 black and 26 medium-brown kids. These results agree with the hypothesis that medium brown $\left(B^{b}\right)$ is recessive to black (wild type $B^{+}$), and that the black goats with a medium-brown parent are heterozygous $\left(B^{b} B^{+}\right)$, while medium-brown goats are homozygous $\left(B^{b} B^{b}\right)$ : $\mathrm{chi}^{2}=3.76,1 d f, P>0.05$. Medium-brown goats mated to medium-brown goats produced 28 medium-brown kids, and no other colors, which is consistent with its being a recessive gene.

The only occasion on which a dark-brown goat with a medium-brown parent was mated to a medium-brown goat the kids were one dark brown and one medium brown.

\section{DISCUSSION}

The homologies and interactions of the various browns in the literature are currently uncertain, although some proposals are now possible. The two different types of brown in the Pygmy goat, described in this report, have distinct patterns of inheritance. Dark brown is dominant to black, and medium brown is recessive to black. Pygmy goat owners rarely cross the two distinct types of brown, and therefore a complete test of allelism was not possible from the data. The single mating of interest for a test of allelism was of a dark-brown animal, carrying medium brown, to a medium-brown goat. The resulting kids, one dark and one medium-brown, are consistent with the two being allelic, but the numbers are too few for this to be a complete test.

The alleles for dark brown and medium brown, plus a wild type allele, can be provisionally assigned to the Brown locus, since considerations of homology suggest that they belong there. The symbol $B^{d}$ is proposed for the dominant dark brown alleles to be in keeping with recommendations of COGNOSAG (1995). This is 
probably the same as the rossa $\left(B^{r}\right)$ color noted in Lauvergne and Howell (1978). The symbol $B^{b}$ is proposed for the recessive medium brown allele (named brown), since this is the allele that is most likely homologous with recessive brown in other species.

The light-brown coat color that is typical of the Toggenburg breed has been assigned to the Brown locus by Adalsteinsson et al (1994), with the symbol $B^{B l}$. The symbol should be changed to $B^{l}$ to be in keeping with past recommendations of COGNOSAG (Millar and Lauvergne, 1990), as well as current COGNOSAG (1995) recommendations. The light brown allele is dominant to wild type. The light brown discussed in Lauvergne and Howell (1978) could be homologous with either the light brown of Adalsteinsson et al (1994), or the medium brown of this report. The absence of segregation data in Lauvergne and Howell (1978) make it difficult to assign their light brown with certainty.

The order of dominance within the Brown locus is probably $B^{l} ? B^{d}>B^{+}>B^{b}$.

\section{REFERENCES}

Adalsteinsson S, Sponenberg DP, Alexieva S, Russell AJF (1994) Inheritance of goat coat colors. J Hered 85, 267-272

Asdell SA, Buchanan Smith AD (1928) Inheritance of color, beard, tassels, and horns in the goat. $J$ Hered 19, 425-430

COGNOSAG (1995) Revised guidelines for gene nomenclature in ruminants (1993) Genet Sel Evol 27, 89-93

Eidregevic EV (1941) A contribution to the problem of morphogenesis and evolution of pigmentation in the goat. Tr Buryat-Mong Zoovet Inst (Ulan-Ude) 2, 173-187 (in Russian); Anim Breed Abstr 14, 237

Hards ER (1950) The inheritance of coat characteristics in the goats of the British Isles. British Goat Society's Year Book 67-69

Lauvergne JJ, Howell WE (1978) Un premier inventaire génétique de la chèvre Corse. Ethnozootechnie 22, 86-88

Millar P, Lauvergne JJ (1990) Loci for coat colour of goats. In: Loci for Coat Colour of Sheep and Goats 1989 (JJ Lauvergne, ed), COGNOSAG, Clamart, France, 59-66 